\title{
Problematika dalam pembelajaran penerjemahan
}

\author{
Aris Wuryantoro \\ Universitas PGRI Madiun, JI. Setiabudi No. 85 Madiun \\ e-mail: allam_71@yahoo.co.id
}

\begin{abstract}
Abstrak
Penerjemahan pada umumnya meliputi dua bahasa yang berbeda dan sistem bahasanya berbeda pula. Selain itu, penerjemahan juga meliputi bidang ilmu dan budaya. Oleh karena itu, bagi mahasiswa yang mendapatkan mata kuliah penerjemahan memiliki problematika yang serius dalam pembelajaran penerjemahan. Tulisan ini mendeskripsikan problematika dalam pembelajaran penerjemahan khususnya untuk mahasiswa di perguruan tinggi. Dalam mengampu mata kuliah penerjemahan, penulis menemukan beberapa problematika yang dimiliki oleh mahasiswa khususnya dalam praktik menerjemahkan teks dari bahasa Inggris ke dalam bahasa Indonesia. Problematika yang dimiliki mahasiswa dalam pembelajaran penerjemahan secara garis besar adalah kompetensi linguistik dan ekstra linguistik. Kompetensi linguistik meliputi penguasaan leksikal dan struktur gramatikal, sementara kompetensi ekstra linguistik meliputi bidang ilmu dan konteks budaya.
\end{abstract}

Kata kunci: penerjemahan, leksikal, struktur gramatikal, bidang ilmu, konteks budaya

\section{Problems in learning translation}

\begin{abstract}
Translation, generally, consists of two different languages and its language systems. Besides, translation also consists of subject matter and culture. This paper aims to describe the problems in learning translation for university students. In teaching translation course, the writer obtains some problems faced by the students, for example translating text from English into Indonesian and vice versa. The students' main problems in learning translation are linguistic and extra-linguistic competence. Linguistic competence consists of lexicon and grammatical structure. Extra-linguistic competence consists of subject matter and cultural context.
\end{abstract}

Keywords: translation, lexicon, grammatical structure, subject matter, cultural context

\section{Pendahuluan}

Penerjemahan merupakan salah satu mata kuliah yang diberikan di program studi pendidikan bahasa Inggris di Universitas PGRI Madiun selama 2 semester, yakni semester 6 dan semester 7. Mata kuliah penerjemahan mencakup teori penerjemahan dan praktik menerjemahkan, baik dari bahasa Inggris ke dalam bahasa Indonesia atau sebaliknya. Dengan diberikannya mata kuliah penerjemahan, mahasiswa diharapkan mempunyai kompetensi baik bahasa Inggris dan bahasa Indonesia serta kompetensi penerjemahan. Kompetensi penerjemahan, pada dasarnya tidak hanya meliputi kompetensi bahasa sumber dan bahasa sasaran, namun lebih dari itu, kompetensi penerjemahan meliputi kompetensi bidang ilmu yang terkait serta kompetensi budaya. Belajar penerjemahan berarti pula belajar budaya karena unsur-unsur budaya 
terkandung dalam bahasa-bahasa yang terlibat dalam penerjemahan (Wuryantoro, 2014:241).

Larson (1984: 3) menjelaskan bahwa penerjemahan meliputi pengalihan makna dari bahasa sumber ke bahasa penerima. Maknalah yang dialihkan dan harus tetap dipertahankan, hanya bentuklah yang berubah. Dalam menerjemahkan, kegiatan untuk menghasilkan terjemahan, maknalah yang harus diperhatikan terlebih dahulu yakni makna tidak boleh berubah. Makna dalam bahasa sasaran harus sesuai dengan makna dalam bahasa sumber. Pada sisi lain, yang dapat berubah hanya bentuknya yakni mengikuti bentuk yang ada dalam bahasa sasaran. Ini dilakukan agar pembaca teks sasaran mudah dalam memahami teks terjemahan.

Penerjemahan tidak hanya berorientasi pada pengalihan makna dan bentuk bahasa, namun penerjemahan juga mencakup leksikal, struktur gramatikal, situasi komunikasi, dan konteks budaya. Seperti yang diungkapkan oleh Larson, "Translation, then, consists of styudying the lexicon, grammatical structure, communication situation, and cultural context of the source language text, analyzing it in order to determine its meaning, and then reconstructing this same meaning using the lexicon and grammatical structure which are appropriate in the receptor language and its cultural context." (1984:3). Ini menunjukkan bahwa dalam penerjemahan, seorang penerjemah harus menguasai leksikal, struktur gramatikal, situasi komunikasi, dan konteks budaya baik dalam bahasa sumber mapunun dalam bahasa sasaran. Unsur leksikal dan struktur gramatikal merupakan bagian dari bahasa (linguistik). Sementara unsur situasi komunikasi dan konteks budaya merupakan unsur non linguistik. Situasi komunikasi adalah situasi atau bidang ilmu dari teks yang terkait dalam penerjemahan, misalnya teks hukum. Konteks budaya sangat erat hubungannya dengan budaya dalam bahasa sasaran. Ketepatan konteks budaya dalam bahasa sasaran merupakan salah satu kriteria terjemahan yang baik dan benar, yakni keberterimaan. Artinya, kata atau istilah dalam terjemahan tersebut dapat diterima atau sesuai atau tidak dengan budaya dalam bahasa sasaran.

Coba perhatikan kalimat atau peribahasa dalam bahasa Inggris sebagai bahasa sumber berikut ini. Bahasa sumber: Kill two birds with one stone. Kalimat ini apabila diterjemahkan secara harfiah akan menjadi, Membunuh dua burung dengan satu batu. Apakah terjemahan tersebut sudah benar? Jawabnya BENAR, apabila ditilik dari unsur leksikal dan struktur gramatikalnya. Namun, apabila ditilik dari unsur situasi komunikasi dan konteks budaya, terjemahan tersebut TIDAK BENAR atau tidak tepat. Mengapa ini terjadi? Terjemahan tersebut karena belum mempertimbangkan unsur situasi komunikasi dan konteks budaya, khususnya konteks budaya bahasa sasaran. Hal ini penting untuk diperhatikan karena konteks budaya bahasa sasaran merupakan bagian dari kriteria keberterimaan dari terjemahan yang baik dan benar. Makna dari kalimat Kill two birds with one stoneadalah dua hal dilakukan dalam satu kali kerja atau satu kali kerja dua pekerjaan dapat diselesaikan. Dalam bahasa Indonesia mengenal kalimat atau peribahasa yang mempunyai makna dua hal dilakukan dalam satu kali kerjaatau satu kali kerja dua pekerjaan dapat diselesaikan, yaitu Sambil menyelam minum airatau Sekali merengkuh dayung, dua tiga pulau terlampaui. Jadi, kalimat atau peribahasa Kill two birds with one stonebila diterjemahkan ke dalam bahasa Indonesia dengan memperhatikan konteks budaya akan dihasilkan terjemahan Sambil menyelam minum air atau Sekali merengkuh dayung, dua tiga pulau terlampaui. Terjemahan ini akan lebih baik dan benar karena sudah mencakup keutuhan makna dan konteks budaya sudah terpenuhi.

Untuk mendapatkan hasil terjemahan yang baik, penerjemah harus memiliki cara tertentu dalam menerjemahkan teks bahasa sumber ke dalam bahasa sasaran. Cara tertentu tersebut dapat berupa strategi penerjemahan dan teknik penerjemahan. Wuryantoro (2014: 236) mengungkapan bahwa penerjemah dalam menciptakan terjemahan yang baik tentunya menggunakan strategi dan teknik penerjemahan yang 
tepat. Strategi penerjemahan adalah cara penerjemah dalam mengatasi masalah dalam proses menerjemahkan teks bahasa sumber ke bahasa sasaran. Wuryantoro (2015: 54-59) membagi strategi penerjemahan menjadi 2 jenis, yaitu (a) strategi penerjemahan secara non-teknis dan (b) strategi penerjemahan secara teknis. Strategi penerjemahan secara non-teknis adalah strategi penerjemahan yang diterapkan oleh penerjemah sebelum atau sesudah menerjemahkan teks bahasa sumber ke dalam bahasa sasaran. Bila dilakukan sebelum proses penerjemahan dimaksudkan untuk mempermudah proses penerjemahan, namun bila dilakukan sesudah proses penerjemahan biasanya dimaksudkan untuk merevisi atau mengklarifikasi hasil terjemahan. Strategi ini meliputi: konfirmasi ke klien, mengidentifikasi teks atau dokumen, membuat catatan, memindai ke dalam perangkat lunak, dan menyiapkan kamus luring dan atau kamus cetak. Di sisi lain, strategi penerjemahan secara teknis strategi penerjamahan yang diterapkan oleh penerjemah untuk mengatasi kendalakendala penerjemahan yang ditemukan pada saat menerjemahkan teks bahasa suimber ke dalam bahasa sasaran. Strategi ini meliputi: kata pinjaman tanpa atau dengan deskripsi, deskripsi, pencarian di jejaring, konsultasi teman sejawat, googling, dan merujuk ke KBBI dan glosarium KBBI.

Sedangkan teknik penerjemahan adalah cara yang diterapkan dalam terjemahan yang dihasilkan dalam teks bahasa sasaran. Molina dan Albir (2002) menawarkan beberapa teknik penerjemahan, yaitu: (a). Adaptasi adalah teknik penerjemahan dengan cara mengganti unsur budaya pada bahasa sumber dengan hal yang sama pada unsur budaya bahasa sasaran, (b). Amplifikasi adalah teknik penerjemahan yang memperkenalkan informasi secara gamblang atau menjelaskan informasi yang tidak tercantum dalam teks bahasa sumber, (c). Peminjaman adalah teknik penerjemahan dengan cara pengambilan langsung suatu kata atau ungkapan dari bahasa lain, (d). Kalke adalah teknik penerjemahan kata atau frase dari bahasa sumber secara harfiah ke dalam bahasa sasaran baik secara leksikal maupun structural, (e). Kompensasi adalah teknik penerjemahan yang memperkenalkan unsur informasi atau pengaruh stilistik teks bahasa sumber pada tempat lain dalam teks bahasa sasaran karena tidak dapat ditempatkan pada posisi yang sama seperti dalam teks bahasa sumber, (f). Deskripsi adalah teknik penerjemahan yang mengganti istilah dengan deskripsi bentuk atau fungsinya, (g). Kreasi diskursif adalah teknik penerjemahan yang membuat suatu padanan sementara yang di luar konteks atau sama sekali tidak dapat diduga. Teknik ini biasanya digunakan pada penerjemahan judul, (h). Padanan lazim adalah teknik penerjemahan yang penggunaan istilah yang telah lazim digunakan baik dalam kamus atau dalam bahasa sasaran sebagai padanan dari teks bahasa sumber tersebut, (i). Generalisasi adalah teknik penerjemahan yang menggunakan istilah yang lebih umum atau netral dalam bahasa sasaran, (j). Amplifikasi linguistik adalah teknik penerjemahan dengan penambahan unsur linguistik pada bahasa sasaran, (k). Kompresi linguistik adalah teknik penerjemahan ini menyederhanakan unsur linguistik dalam bahasa sasaran, (I). Terjemahan harfiah adalah teknik penerjemahan dengan cara menerjemahkan per-kata atau secara kata per kata, $(\mathrm{m})$. Modulasi adalah teknik penerjemahan dengan penggantian sudut pandang, fokus atau kategori kognitif yang berkenaan dengan teks bahasa sumber; bisa dalam bentuk struktural maupun leksikal, (n). Penggunaan bentuk khusus adalah teknik penerjemahan yang menggunakan istilah secara lebih spesifik dan konkrit bukan pada bentuk umumnya, (0). Pengurangan adalah teknik penerjemahan yang menyiratkan informasi karena komponen maknanya sudah termasuk dalam bahasa sasaran, (p). Subtitusi adalah teknik penerjemahan yang menggunakan penggantian unsur-unsur linguistik dengan paralinguistik (intonasi, gesture) dan sebaliknya, (q). Transposisi adalah teknik penerjemahan dengan cara penggatian kategori gramatikal, misal dari verb menjadi adverb dsb, ataupun perubahan tempat kata, misal adjectivenoun menjadi noun- adjective, (r). Variasi adalah teknik penerjemahan dengan 
menggunakan teknik penggantian unsur linguistik atau para linguistik (intonasi, gestur) yang mempengaruhi aspek keragaman linguistik: penggantian gaya, dialek sosial, dialek geografis.

\section{Metode Penelitian}

Penelitian ini menggunakan metode kualitatif deskriptif dengan teknik simak catat pada dokumen yang berupa hasil terjemahan mahasiswa dari teks bahasa Inggris ke dalam bahasa Indonesia sebaliknya sebaliknya. Dokumen yang berupa terjemahan dianalisis untuk mengidentifikasi dan mendeskripsi problem-problem yang dihadapi mahasiswa dalam pembelajaran penerjemahan. Berdasarkan teori penerjemahan, problematika dalam pembelajaran penerjemahan yang dimiliki mahasiswa tercemin dari hasil terjemahan yang dihasilkannya.

\section{Hasil dan Pembahasan}

Beberapa kasus yang mendapat sorotan dalam pembelajaran penerjemahan khususnya pada praktik menerjemahkan, baik dari bahasa Inggris ke dalam bahasa Indonesia atau sebaliknya. Misalnya seperti kasus berikut ini.

That woman is pretty-pretty terjemahan dari gadis itu cantik-cantik. Dalam kasus ini, penerjemah masih kurang dalam penguasaan kompetensi linguistiknya, yaitu yang berhubungan dengan leksikal dan struktur gramatikal. Terjemahan ini masih sangat kaku dan penerjemah hanya mengetahui arti kamus dari bahasa Indonesia ke bahasa Inggris, gadisartinya woman, dan cantik artinya pretty. Sehingga penerjemah dalam menerjemahkangadis itu cantik-cantikkebahasa Inggris menjadi that woman is pretty-pretty. Ini menunjukkan bahwa penerjemah dalam hal pemilihan kata, leksikal, masih salah untuk kata woman dan pretty kurang tepat untuk terjemahan dari gadis dan cantik. Selain itu penyusunan kalimatnya juga belum sesuai dengan kaidah bahasa Inggris. Bahasa Indonesia mengenal hukum DM (Diterangkan-Menerangkan), yakni kata sifat yang berfungsi menerangkan kata benda hadir setealh kata benda, seperti gadis cantik. Kata gadis adalah kata benda yang diterangkan, sedangkan kata cantik adalah kata sifat yang menerangkan kata benda, gadis. Sebaliknya, bahasa Inggris mengenal hukum MD (Menerangkan-Diterangkan), yakni kata sifat yang berfungsi menerangkan kata benda hadir sebelum kata benda yang berfungsi diterangkan, seperti beautiful girl. Kata beautiful (kata sifat) hadir sebelum kata girl (kata benda). Di samping itu, bahasa Inggris tidak mengenal pengulangan kata, seperti pretty-pretty(cantik-cantik), tall-tal/(tinggi-tinggi), dan sebagainya. Penulisan kata yang menunjukkan jamak terjadi pada kata benda dengan menambahkan huruf $-s$, atau -es di belakang kata benda, seperti girls, heroes, buildings, dan sebagainya. Namun, sebaliknya bahasa Indonesia mengenal kata pengulanga, seperti cantik-cantik, tinggitinggi, dan sebagainya yang menunjukkan kata sifat atau keterangan untuk kata benda, seperti gadis itu cantik-cantik, gedung itu tinggi-tinggi.Jadi terjemahan dari gadis itu cantik-cantik adalah Those girls arebeautiful atau Those are beautiful girls.

Perhatikan pula kasus di bawah ini.

Teks Bahasa Sumber (TBSu):

I, .......having authority under the Marriage Act 1961 to solemnize marriage, hereby certify that $I$ have this day at ..................... duly solemnized marriage in accordance with the provisions of that Act between................ and .......in the presence of the undersigned witnesses. Teks Bahasa Sasaran (TBSa):

Saya ............yang memiliki kewenangan menurut Undang-Undang Perkawinan tahun 1961 untuk melangsungkan perkawinan, dengan ini saya menerangkan bahwa pada hari ini ..................melangsungkan perkawinan sebagaimana 
mestinya sesuai dengan ketentuan Undang-Undang antara....................dan dengan dihadiri para saksi yang bertanda tangan di bawah ini.

Klausa I, .......having authority under the Marriage Act 1961 to solemnize marriage, diterjemahkan menjadi Saya ............yang memiliki kewenangan menurut Undang-Undang Perkawinan tahun 1961 untuk melangsungkan perkawinan. Penerjemah menerjemahkan to solemnize marriagemenjadi untuk melangsungkanperkawinandapat menjadi fatal akibatnya. Istilah melangsungkan perkawinan identik dengan yang melaksanakan perkawinan, yaitu ke dua mempelai baik mempelai laki-laki atau mempelai perempuan. Bila merujuk dari kata-kata sebelumnya, $I$, .......having authority under the Marriage Act 1961 yang artinya Saya ............yang memiliki kewenangan menurut UndangUndang Perkawinan Tahun 1961, istilah melangsungkan perkawinankurang tepat karena yang berbicara di sini (Saya) memiliki kewenangan menurut UndangUndang Perkawinan Tahun 1961 adalah seseorang yang memimpin upacara pelaksanaan perkawinan (pernikahan) atau seseorang yang mengesahkan perkawinan (pernikahan). Orang yang mengesahkan perkawinan (pernikahan) di Indonesia adalah penghulu atau pendeta atau pemimpin agama terkait.

Kasus ini terjadi karena penerjemah tidak memiliki latar belakang bidang ilmu (situasi komunikasi) dan konteks budaya. Bila menilik dari tipologi teks, tersebut adalah teks dokumen (legal text) yang pastinya sangat terikat oleh sistem hukum dan budaya dari bahasa terkait. Oleh karena itu, idealnya penerjemah harus memiliki kompetensi bidang ilmu atau konteks budaya agar hasil penerjemahannya dapat berterima.

Kembali ke kasus di atas, penulis memberi alternatif terjemahan yang lebih dapat berterima dengan mengganti istilah melangsungkan perkawinandenganmengesahkan perkawinan. Coba kita perhatikan terjemahan berikut. Saya,...................dengan kewenangan di bawah Undang-undang Perkawinan 1961 untukmengesahkan perkawinan (pernikahan), dengan ini menyatakan bahwa saya telah hari ini pada .......................telah mengesahkan perkawinan sesuai dengan ketentuan Undang-undang antara ..................... dan .............. di hadapan saksisaksi yang bertandatangan di bawah ini. Dengan menggunakan istilah mengesahkan perkawinan (pernikahan), pembaca langsung mendapatkan makna yang sesuai dengan isi dari teks, yakni orang yang berwenang untuk mengesahkan suatu proses atau upacara perkawinan (pernikahan). Dengan demikian, terjemahan akan lebih berterima bagi pembacanya karena tidak dibingungkan lagi makna yang terkandung dari istilah yang digunakan dalam terjemahan

\section{Kesimpulan}

Menilik dari kasus-kasus terjemahan yang didiskusikan di atas, penulis menyimpulkan bahwa problematika dalam pembelajaran penerjemahan ada dua kutub yakni problematika pada teks bahasa sumber dan problematika pada teks bahasa sasaran. Ke dua teks tersebut memiliki problematika yang sama yakni problematika pemilihan leksikal (makna) sesuai konteks, struktur gramatika (penyusunan kalimat) sesuai kaidah bahasa, situasi komunikasi sesuai dengan bidang ilmu dalam teks, dan konteks budaya yang disesuaikan dengan budaya bahasa sasaran. Untuk mendapatkan terjemahan yang akurat, terbaca dan berterima diperlukan kompetensi yang wajib dimiliki oleh seorang penerjemah yang sekaligus merupakan problematika bagi penerjemah, yaitu kompetensi linguistik dan kompetensi ekstra linguistik. 


\section{Daftar Pustaka}

Wuryantoro, A. (2014). "Belajar Budaya Melalui Penerjemahan". Dalam Inayatillah, Fafi. dkk (Eds.), Membangun Budaya Literasi (hal. 230-243). Surabaya: Unesa University Press

Wuryantoro, A. (2014). Kajian Proses Penerjemahan dan Kualitas Terjemahan Teks Hukum dan Teks Ilmiah Bidang Hukum Karya Penerjemah Tersumpah. Disertasi. Surakarta: PPS UNS

Wuryantoro, A. (2015). Pernak-Pernik Penerjemahan. Madiun: Institut Press IKIP PGRI Madiun

Larson, M.L. (1984). Meaning-Based Translation: A Guide to Cross LanguageEquivalence. Lanham: University Press of America.

Molina, L \& Albir, A.H. (2002). "Translation Techniques Revisited: A Dynamic and Functionlist Approach". Meta: Translators' Journal. vol. 47, no. 4, pages. 498 512. 